\title{
The design and construction of the River Rother cable-stayed footbridge, Rother Valley Park
}

\author{
M. C. Wilson and R. D. Bell
}

\section{Mr A. C. G. Hayward, Cass Hayward \& Partners}

The single tower design for the cable stayed footbridge is conveniently able to deal with the problem should the west bank seat subside. The Authors state that a single span lattice girder bridge would have been comparable in price. My own experience in such cases is that cable stayed or suspension bridges, when on a small scale, can cost up to twice the amount of the perhaps mundane beam or lattice girder solution. It is stated in the Paper that the chosen design would probably attract a 'complexity' premium. This must surely have been so when they mention that the first round of tenders drew high prices from the major steel bridge fabricators. Perhaps the later lower priced tenderers were looking to the engineer to provide them with the expertise they needed. Was the erection scheme, which seems fairly involved, suggested by the engineer or was it proposed by the contractors?

63. In this context, it is noted that precamber details were calculated by the engineer and not by the contractor. This is a current source of considerable problems in Department of Transport contracts where the standard specification calls for precambers to be calculated by the contractor. For composite steel bridges especially, the calculations involved are lengthy and require intricate knowledge of the design assumptions. The engineer is really the only party with all the information needed to calculate precambers. It means, however, that the engineer must be fully experienced in the likely construction methods to be used so as to be able to design and illustrate a viable sequence on the working drawings. If then the contractor wishes to change the construction sequence he must recalculate the precamber himself and submit full information for checking by the engineer. In my opinion, the current Department of Transport specifications should be amended such that the contractor constructs precamber to the values specified on the engineer's drawings.

64. Turning to detail, it is noted that the tapered tower legs are formed from split hollow sections, reformed with infill plates. Was distortion experienced in making the splitting operation, needing extensive straightening operations? If so, would it have been better to use legs made from channel sections and taper infill plates, or even to use fabricated legs? The hardwood in the deck used is perhaps another unusual solution for a permanent structure. What is its life expectancy and how does its overall economy compare with, say, a. $6 \mathrm{~mm}$ stiffened steel plate with epoxy surfacing?

65. The Authors' detail for the connection between cables and the deck is of interest in making use of a $50 \mathrm{~mm}$ thick Hyzed plate. Clearly, this detail must have

Paper published: Proc. Instn Civ. Engrs, Part 1, 1985, 78, June, 545-563. 


\section{DISCUSSION}

been fairly expensive and difficult to fabricate on account of the slotting in required of the cable stub and Hyzed plate into the hollow section chord. A similar detail was incorporated in a suspension footbridge I was involved with some years ago. The hanger to deck detail made use of twin slotted plates into the hollow section chord, which projected through both vertical webs. This avoided the use of steel with through thickness property, but the forces involved were obviously considerably less than in the Authors' design. ${ }^{7}$

\section{Mr Wilson and Mr Bell}

On the question of costs, despite comparable costs for material content, it was always recognized that site fabrication, erection procedures and other factors such as the choice of a suitable contractor would result in the cable stayed bridge being more expensive than a single span lattice girder solution. Both rounds of tendering were on the same basis so that the low priced tenderers had no grounds for assuming an increased role for the Engineer.

67. The contractor was free to choose his own erection scheme, subject to the approval of the Engineer who under the terms of the contract had to be provided with specified details. The Engineer then had four weeks from receipt of this information to supply shop cambers. This procedure worked well and had the benefit of not restricting the contractor's preferred working methods. We would agree with $\mathrm{Mr}$ Hayward that the engineer responsible for the design is best able to make the calculations. In the context of composite steel bridges generally the designer having had to consider a construction sequence in preparing his design could easily make available pre-camber details.

68. The possibility of distortion occurring on splitting the hollow sections for the tower legs was recognized prior to fabrication. The fabricator had considerable experience of working with rectangular hollow sections and adopted a sequence of ' hit and miss' cuts combined with local treatment. This resulted in virtually no distortion. The rounded corners of hollow sections were judged to be more pleasing in this situation.

69. In the choice of a hardwood deck the Authors took account of the client's view that this would be in keeping with a country park. Had the design vehicular loading been higher a steel deck would have been required. The hardwood is expected to have a life exceeding 40 years. Its initial cost including installation was $£ 44$ per square metre at 1983 prices.

70. The Authors would agree that the use of $50 \mathrm{~mm}$ Hyzed plate was expensive. The detail adopted for connecting the cables with the deck arises from the need to have extended transverse members so that the required headroom envelope could be achieved and the desire to have these transverse members within the depth of the main booms. Outside the main booms the transverse members are aligned in a plane normal to the inclination of the cables. This alignment could not be maintained between the main booms owing to the limited depth below the timber deck. The Hyzed transfer plate was therefore required to cater for tensile forces applied in the through thickness direction.

\section{Reference}

7 Hayward A. C. G. Suspension at Newtown (Wales). Acier, Brux., 1975, No. 1, Jan, 13-18. 